\title{
PENGEMBANGAN MULTIMEDIA INTERAKTIF DALAM PEMBELAJARAN GEOMETRI UNTUK MENINGKATKAN KEMAMPUAN KOMUNIKASI CALON GURU SEKOLAH DASAR
}

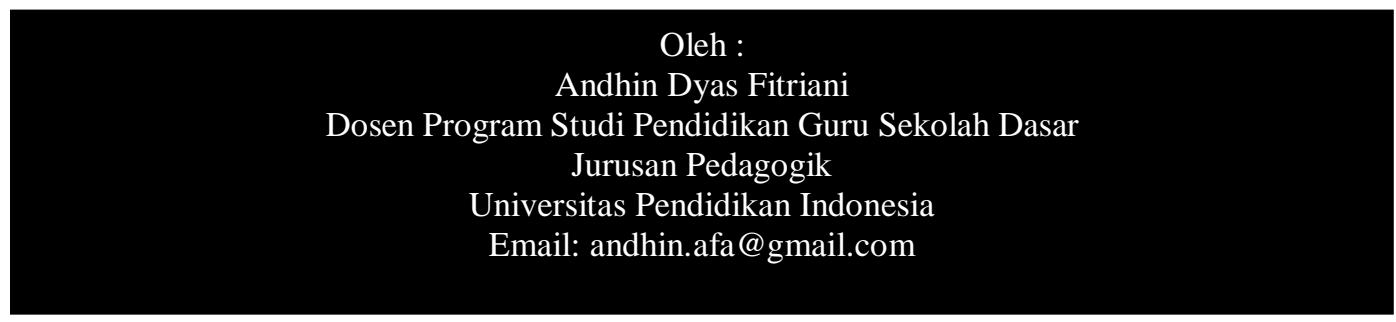

Abstract. Communication is an essential part of mathematics and mathematics education. Communication is also a way to share ideas and classify understanding. Geometry in elementary school (SD) on the one hand is a very strategic mathematics study to encourage mathematics learning towards appreciation and experience of learning by making the learning meaningful. Van Hiele suggests that there are three main elements in the teaching of geometry, namely time, teaching materials, and teaching methods applied. One of the things that hinder a student's geometric thinking skills is the teaching methods employed by teachers in the classroom. The role of teachers in the 21 st century includes "teacher as learners - who always improve and renew their knowledge". Teachers should be able to create an independent learning atmosphere which captivates and attracts students to learn in a pleasant atmosphere. One technology that can be applied is learning multimedia. Multimedia in learning covers several aspects of the synergy between text, graphics, images and animation. The use of multimedia is expected to enhance the learning of mathematics as it allows a wider exploration and can improve the presentation of mathematical ideas.

Keywords: Interactive Multimedia, Geometry, Communication Capabilities

Abstrak, Komunikasi merupakan bagian yang esensial dari matematika dan pendidikan matematika. Komunikasi juga merupakan cara untuk berbagi gagasan dan mengklasifikasikan pemahaman.Geometri di sekolah dasar (SD) di satu pihak merupakan kajian matematika yang sangat strategis untuk mendorong pembelajaran matematika ke arah apresiasi dan pengalaman matematika dengan cara belajar matematika secara bermakna. Van Hiele mengemukakan bahwa terdapat tiga unsur utama dalam pengajaran geometri, yaitu waktu, materi pengajaran, dan metode pengajaran yang diterapkan. Salah satu hal yang menghambat kemampuan berpikir geometri seorang siswa adalah metode pengajaran yang diterapkan oleh guru di kelas. Peran guru pada abad ke-21 diantaranya adalah "teacher as learners - who always improve and renew theri knowledge". Guru harus dapat menciptakan suatu pembelarajan yang berpotensi menciptakan suasana belajar mandiri, serta mampu memikat dan menarik siswa untuk belajar dalam suasana yang menyenangkan. Salah satu teknologi yang dapat diterapkan dalam pembelajaran adalah penggunaan multimedia dalam pembelajaran. Multimedia dalam pembelajaran mencakup beberapa aspek yang bersinergi antara teks, grafik, gambar dan animasi. Melalui multimedia diharapkan dapat meningkatkan proses belajar matematika karena memungkinkan eksplorasi yang lebih luas dan dapat memperbaiki penyajian ide-ide matematika.

Kata Kunci : Multimedia interaktif, Geometri, Kemampuan Komunikasi

\section{A. PENDAhuluan}

Komunikasi merupakan bagian yang esensial dari matematika dan pendidikan matematika. Komunikasi juga merupakan cara untuk berbagi gagasan dan mengklasifikasikan pemahaman. Gagasan 
Edutech, Tahun 13, Vol.1, No.2, Juni 2014

yang disampaikan pada pembelajaran matematika dapat berupa memberikan laporan, penjelasan lisan, menggunakan diagram, menulis, dan menggunakan simbol matematika. Cockroft (Shadiq, 2004: 23) menyatakan bahwa perlunya belajar matematika dikarenakan bahwa matematika merupakan alat komunikasi yang sangat kuat, teliti dan tidak membingungkan. Depdiknas (Shadiq, 2004: 20) menyatakan bahwa banyak persoalan ataupun informasi disampaikan dalam bahasa matematika, mengkomunikasikan gagasan dengan bahasa matematika justru lebih praktis, sistematis dan efisien, sehingga bahasa matematika merupakan bagian dari bahasa yang digunakan dalam masyarakat. Oleh karena itu, proses komunikasi dapat membantu siswa dalam menyampaikan gagasan mereka sehingga gagasan tersebut dapat diketahui oleh orang lain.

NCTM membagi menjadi lima standar isi pada kegiatan pembelajaran matematika, yaitu bilangan dan operasinya, aljabar, geometri, pengukuran serta analisis data dan probabilitas. Selain menjabarkan lima standar isi matematika, NCTM juga menjabarkan enam prinsip dasar untuk mencapai pendidikan matematika yang berkualitas tinggi, yaitu kesetaraan, kurukulum, pengajaran, pembelajaran, penilaian, dan teknologi.
Salah satu standar isi matematika yaitu geometri. Geometri merupakan kajian matematika yang sangat strategis untuk mendorong pembelajaran matematika ke arah apresiasi dan pengalaman matematika dengan cara belajar matematika secara bermakna. Sifat visual dan representasinya menjadikan geometri dapat mendukung siswa untuk memahami konsep bilangan dan pengukuran. Aktivitas pemecahan masalah dalam geometri merupakan aktivitas yang baik untuk perkembangan berpikir siswa karena berhubungan dengan ruang, konstruktif, serta terkait dengan dunia nyata. Di pihak lain, posisi geometri seperti itu tidak banyak mempengaruhi proses dan hasil pembelajaran matematika di kelas.

Van Hiele (Herman, 2006) mengemukakan bahwa terdapat tiga unsur utama dalam pengajaran geometri, yaitu waktu, materi pengajaran, dan metode pengajaran yang diterapkan. Van Hiele juga berpendapat bahwa jika ketiga unsur tersebut ditata secara terpadu, maka akan dapat meningkatkan kemampuan berpikir anak kepada tingkatan berpiki yang lebih tinggi. Salah satu hal yang menghambat kemampuan berpikir geometri seorang siswa adalah metode pengajaran yang diterpkan oleh guru di kelas.

Van Hiele mengenalkan lima tahap perkembangan berpikir yang mencirikan 
kualitas pemahaman, yaitu: (1) tahap visualisasi; (2) tahap analisis; (3) tahap deduksi informal; (4) tahap deduksi; dan (5) tahap rigor. Pengembangan berpikir geometri siswa SD hanya cocok sampai tahap deduksi informal.

Pada tahap visualisasi, siswa mengenal konsep geometri semata-mata didasarkan pada karakteristik visual atau penampakan bentuknya. Dalam mengidentifikasikan bangun, siswa seringkali menggunakan prototipe visual. Siswa pada tahap berpikir ini belum bisa memahami atau menentukan sifat geometri dan karakteristik bangun yang ditunjukkan dan belum menyadari karakteristik bangun meskipun bangun itu telah ditentukan berdasarkan karakteristiknya. Pada tahap analisis, siswa menyadari dan dapat mencirikan bentuk bangun geometri berdasarkan sifatnya dan sudah tampak adanya analisis terhadap konsep geometri. Meskipun demikian, siswa belum sepenuhnya bisa menjelaskan hubungan antara sifat bangun atau belum bisa melihat hubungan antara berbagai bangun dan belum bisa memahami definisi. Pada tahap deduksi informal, siswa sudah dapat melihat hubungan sifat pada suatu bangun. Siswa sudah bisa menyatakan hubungan antara beberapa bangun. Dalam hal ini, penalaran siswa sudah dapat membuat definisi abstrak dan dapat memberikan argumen informal serta mengklasifikasi bangun secara hirarkis (mengurutkan sifat).

Seseorang yang belajar geometri dalam perspektif teori Van Hiele (Clements \& Battista, 1992) akan menunjukkan ciri perkembangan yang unik pada cara berpikirnya. Pertama, belajar merupakan suatu proses yang diskontinu, yaitu terdapat suatu lompatan pada kurva belajar seseorang yang menandakan adanya tahap berpikir diskrit dan berbeda secara kualitatif. Seseorang yang mencapai suatu tahap akan tetap pada tahap itu untuk waktu tertentu dan seolah-olah menjadi matang. Kedua, tahapan itu berurutan dan hirarkis. Artinya, untuk bekerja dengan baik pada tahap berikutnya, siswa harus menguasai sebagian besar tugas pada tahap yang lebih rendah. Perkembangan dari satu tahap ke tahap berikutnya tidak ditentukan oleh kematangan biologis atau usia seseorang, melainkan lebih bergantung pada pembelajaran dan pengalaman. Ketiga, konsep yang implisit pada satu tahap akan menjadi eksplisit pada tahap berikutnya. Keempat, setiap tahap mempunyai bahasa tersendiri. Menurut pandangan van Hiele, pembelajaran geometri hanya akan efektif apabila sesuai dengan struktur kemampuan berpikir siswa.

Untuk memperoleh hasil belajar yang diharapkan, van Hiele menawarkan model pembelajaran yang terdiri dari lima fase, yang sekaligus sebagai tujuan 
Edutech, Tahun 13, Vol.1, No.2, Juni 2014

pembelajaran (Crowley, 1987), sebagai berikut

1. Fase inkuiri/informasi, konsep baru yang dipelajari diperkenalkan melalui tanya jawab antara guru dengan siswa. Guru mempelajari perbendaharaan bahasa dan interpretasi siswa yang diwujudkan dalam bentuk pertanyaan yang dirancang secermat mungkin. Guru akan memperoleh informasi tentang pengetahuan awal siswa untuk materi yang dipelajari, sedangkan siswa memperoleh gambaran tentang arah belajarnya.

2. Fase orientasi terarah, guru mengarahkan siswa meneliti obyek yang dipelajari dan merupakan rangkaian tugas singkat untuk memperoleh respon khusus siswa. Aktivitas ini bertujuan untuk merangsang siswa agar aktif mengeksplorasi obyek (misalnya sifat bangun yang dipelajari) melalui kegiatan seperti: melipat, mengukur untuk menemukan hubungan sifat dari bentukbentuk bangun tersebut.

3. Fase uraian, guru mendorong siswa untuk berbagi persepsi (pengalaman) tentang struktur bangun yang diamati dengan menggunakan bahasanya sendiri melalui kegiatan diskusi. Pada fase ini siswa berpeluang untuk menguraikan pengalaman, mengekspresikan, dan mengubah/melepas pengetahuan intuitif mereka yang tidak sesuai struktur bangun yang diamati.

4. Fase orientasi bebas, siswa ditantang dengan situasi masalah yang kompleks supaya memecahkan masalah sesuai caranya sendiri. Hal ini bertujuan agar siswa memperoleh pengalaman menyelesaikan permasalahan dalam belajar dan menggunakan strateginya sendiri. Peran guru adalah memilih materi dan soal geometri yang sesuai untuk pembelajaran sehingga memperoleh berbagai performansi siswa.

5. Fase integrasi, siswa membuat tinjauan dan ringkasan tentang seluruh materi yang telah dipelajari (pengamatan, membuat sintesis dari konsep dan hubungan baru). Tujuan kegiatan ini adalah 
mengintegrasikan pengetahuan yang telah diamati dan didiskusikan. Peran guru membantu mengintegrasikan pengetahuan siswa dengan meminta mereka supaya membuat refleksi dan klarifikasi atas pengetahuan geometrinya.

Pembelajaran matematika di setiap jenjang pendidikan mengacu pada dua tujuan pokok, yaitu tujuan formal dan tujuan material (Soedjadi, 1992). Tujuan formal pembelajaran matematika adalah tujuan yang barkaitan dengan penataan nalar dan pembentukan sikap peserta didik, sedangkan tujuan material pembelajaran matematika adalah tujuan yang berkaitan dengan penggunaan dan penerapan matematika, baik dalam matematika itu sendiri maupun bidang-bidang lainnya. Sejalan dengan pendapat tersebut, hakekat pendidikan matematika (Sumarmo, 2002) mempunyai dua arah pengembangan, yaitu pengembangan untuk kebutuhan masa kini dan masa akan datang.

Pengembangan kebutuhan masa kini yang dimaksud adalah pembelajaran matematika mengarah pada pemahaman konsep-konsep yang diperlukan untuk menyelesaikan masalah matematika dan ilmu pengetahuan lainnya. Sedangkan yang dimaksud dengan kebutuhan di masa yang akan datang adalah pembelajaran matematika yang memberikan kemampuan nalar dan logis, sistematis, kritis, dan cermat serta berpikir objektif dan terbuka seiring tantangan di era globalisasi.

Globalisasi ditandai dengan kemajuan di bidang Teknologi Informasi dan Komunikasi. Kemajuan di bidang Teknologi Informasi dan Komunikasi mendorong terjadinya perubahan di bidang pendidikan. Perubahan tersebut seiring dengan perkembangan masyarakat yang bertumpu pada "masyarakat berbasis pengetahuan" (knowledge-based society).

Dalam bidang pendidikan, perubahan tersebut berpengaruh terhadap sistem pembelajaran. Perubahan paradigma pembelajaran beralih dari paradigma yang berpusat pada "mengajar" menjadi berpusat pada "belajar". Paradigma yang berpusat belajar berorientasi pada pencapaian tujuan dalam rangka mempersiapkan siswa menjadi manusia yang dapat belajar secara mandiri (independent learners).

Oleh karena itu, guru sebagai tenaga profesional harus terus melakukan perubahan-perubahan atau sedikitnya penyesuaian dalam paradigma strategi, pendekatan, dan tekonologi pembelajaran. Sebagaimana dikemukakan oleh Gerstnet, dkk (Supriadi, 2002) bahwa peran guru pada abad ke-21 diantaranya adalah "teacher as learners - who always improve and renew theri knowledge". Guru harus 
dapat menciptakan suatu pembelarajan yang berpotensi menciptakan suasana belajar mandiri, serta mampu memikat dan menarik siswa untuk belajar dalam suasana yang menyenangkan.

Hal tersebut dapat dilakukan dengan mengintegrasikan teknologi dalam proses pembelajaran. Dengan memanfaatkan teknologi, menurut Centron (1988), proses belajar untuk menguasai ilmu pengetahuan dan teknologi semakin cepat dan hemat waktu dan prosesnya akan semakin individual sesuai dengan kebutuhan setiap siswa, tetapi sekaligus massal.

Dalam kegiatan pembelajaran, teknologi Informasi dan Komunikasi memiliki tiga fungsi utama, yaitu teknologi sebagai alat (tools), teknologi sebagai ilmu pengetahuan (science), dan teknologi sebagai bahan dan alat bantu pembelajaran (literacy). Teknologi sebagai alat berfungsi untuk membantu siswa dalam pembelajaran. Teknologi sebagai ilmu pengetahuan merupakan salah satu bagian dari disiplin ilmu yang harus dikuasai oleh siswa. Serta teknologi sebagai bahan dan alat bantu dalam pembelajaran berfungsi memberikan bantuan kepada siswa untuk lebih menguasai kompetensi yang akan dicapai.

Salah satu teknologi yang dapat diterapkan dalam pembelajaran adalah penggunaan multimedia dalam pembelajaran. Multimedia dalam pembelajaran mencakup beberapa aspek yang bersinergi antara teks, grafik, gambar dan animasi. Melalui multimedia diharapkan dapat meningkatkan proses belajar matematika karena memungkinkan eksplorasi yang lebih luas dan dapat memperbaiki penyajian ide-ide matematika. Seperti yang telah diungkapkan sebelumnya, salah satu faktor yang dapat menghambat kemampuan geometris siswa adalah metode pengajaran dalam penyampaian materi geometri. Salah satu upaya yang dapat dilakukan untuk meningkatkan kemampuan geometris siswa adalah dengan penerapan multimedia yang dapat membantu siswa dalam memahami konsep geometri.

Salah satu hal yang harus dilakukan dalam mempersiapkan pembelajaran dengan menggunakan multimedia interaktif adalah bagaimana mengembangkan multimedia tersebut. Dalam mengembangkan multimedia pembelajaran interaktif ada beberapa tahapan pengembangan yang dapat dilakukan. Tahapan tersebut yaitu: concept, design, material, collecting, assembly, testing, dan distribution (Sutopo, 2003).

Pada tahap concept, perlu ditentukan tujuan dan siapa pengguna dari program multimedia interaktif. Tujuan multimedia dibuat dapat untuk hiburan, pelatihan, pembelajaran, dan lainnya. Kemudian 
tentukan siapa pengguna dari multimedia yang akan dibuat, dalam hal ini tentu saja siswa. Tahap selanjutnya adalah tahap design. Pada tahap ini perlu dibuat spesifikasi mengenai arsitektur program. Arsitektur program dapat mencakup tampilan dan gaya dari multimedia tersebut. Selain arsitektur program, pada tahap ini juga dirancang kebutuhan material atau bahan untuk program. Tahap ketiga yaitu material collecting. Tahap ini dilakukan pengumpulan bahan yang sesuai dengan kebutuhan yang akan dilakukan. Untuk tahap ini dapat dikerjakan secara parapel dengan tahap assembly atau dengan tahap linier. Tahap keempat adalah tahap assembly. Tahap ini merupakan tahap pembuatan, dimana semua objek dan bahan multimedia dibuat. Proses pembuatan dapat melibatkan tenaga spesialis yang terampil atau mampu menggunakan beberapa software. Pembuatan aplikasi ultimedia di tahap ini berdasarkan pada storyboard dan struktur navigasi yang berasal dari tahap desain. Setelah selesai tahap pembuatan (assembly), dilanjutkan dengan tahap testing. Pada tahap testing dilakukan ujicoba apakah aplikasi atau program yang telah dibuat terdapat kesalahan ataukah tidak. Tahap ini disebut juga dengan tahap pengujian alpha, dimana pengujian dilakukan oleh pembuat atau lingkungan pembuatnya sendiri. Tahap terakhir dari proses pengembangan multimedia yaitu tahap distribution. Pada tahap ini diputuskan di mana aplikasi disimpan dalam suatu media penyimpanan. Jika media penyimpanan tidak cukup untuk menanpung aplikasi, maka dilakukan kompresi terhadap aplikasi tersebut.

\section{Metode}

Penelitian ini merupakan pengembangan atau dikenal juga dengan istilah Research And Development (R\&D). Karena dari penelitian ini diharapkan diperoleh suatu media pembelajaran berbentuk multimedia interaktif yang dapat digunakan sebagai media untuk meningkatkan kemampuan geometris siswa sekolah dasar. Hal ini bersesuaian dengan pendapat Sugiyono (2009) yang menyatakan bahwa R\&D (Research and Development) adalah metode penelitian yang digunakan untuk menghasilkan produk tertentu, dan menguji keefektifan produk tersebut.

\section{B. HASIL DAN PEMBAHASAN}

Penelitian ini diawali dengan melakukan studi tentang multimedia interaktif. Tahap tersebut bertujuan agar peneliti dapat mengembangkan sebuah multimedia interaktif yang tepat untuk calon guru Sekolah Dasar. Untuk itu dalam pengembangan multiedia interaktif yang akan digunakan, peneliti mengkombinasikan beberapa elemen, yaitu teks, grafis, dan animasi. Sehingga 
diharapkan, multimedia interaktif yang dikembangkan dapat mengembangkan kemampuan komunikasi calon guru yang mempunyai tingkat kemampuan kognitif yang berbeda-beda.

Setelah melalui tahap studi tentang multimedia interaktif, tahap selanjutnya adalah melakukan tes kemampuan awal calon guru Sekolah Dasar. Tes kemampuan awal terdiri dari 5 soal essay yang berisi tentang materi bangun datar. Tes ini dilakukan bertujuan untuk mengetahui sampai sejauhmana kemampuan komunikasi matematis calon guru. Indikator yang digunakan sesuai dengan tahap perkembangan Van Hielle dan kemampuan komunikasi matematis. Kegiatan yang dilakukan selanjutnya adalah perumusan rancangan media pembelajaran. Kegiatan ini meliputi: kegiatan design, kegiatan material collecting, kegiatan assembly.

Pada tahap design dibuat spesifikasi mengenai arsitektur program. Arsitektur program dapat mencakup tampilan dan gaya dari multimedia tersebut. Tampilan dan gaya yang dibuat pada multimedia interaktif ini disesuaikan dengan tahap perkembangan siswa Sekolah Dasar agar calon guru Sekolah Dasar dapat belajar mengenai tampilan dan gaya multimedia interaktif sehingga dapat diterapkan nantinya saat calon guru sudah mengajar di Sekolah Dasar. Rancangan warna dan animasi dari multimedia interaktif ini di desain semenarik mungkin. Tahap selanjutnya yaitu tahap material collecting. Pada tahap ini dilakukan pengumpulan dan perancangan meteri ajar sesuai dengan materi pelajaran yang telah dipilih. Materi pelajaran yang dipilih yaitu bangun datar dan bangun ruang. Selanjutnya dilakukan tahap assembly. Pada tahap ini peneliti dibantu oleh beberapa tenaga yang terampil dalam pembuatan aplikasi multimedia pembelajaran berdasarkan pada storyboard dan struktur navigasi yang telah dirancang pada tahap desain.

Setelah dilakukan perancangan media pembelajaran berupa multimedia interaktif, selanjutnya dilakukan reviu multimedia pembelajaran tersebut oleh satu orang ahli. Dari hasil reviu diperoleh hasil bahwa masih terdapat beberapa kekurangan dari multimedia interaktif tersebut. Kekurangan tersebut antara lain dari segi warna, animasi, dan tata bahasa. Setelah mendapatkan reviu dari ahli tersebut, peneliti dibantu dengan tenaga pembuat aplikasi multimedia interaktif merevisi halhal yang perlu diperbaiki.

Kegiatan selanjutnya yaitu melakukan uji coba media pembelajaran dilakukan di Program Studi Pendidikan Guru Sekolah Dasar Semester II. Uji coba media pembelajaran dilaksanakan selama 3 kali pertemuan. Uji coba media pembelajran dimaksudkan untuk mengetahui 
sejauhmana tingkat efektivitas media pembelajaran tersebut serta untuk melihat kemampuan geometris dan kemampuan komunikasi matematis menggunakan multimedia interaktif.

Dari hasil tahap uji coba, langkah yang dilakukan selanjutnya adalah evaluasi dari media yang telah dibuat. Hal tersebut berdasarkan dari respon mahasiswa dan tanggapan dosen yang terlibat. Sebagian besar (87\%) mahasiswa lebih senang belajar materi geometri dengan menggunakan multimedia interaktif. Sebagian besar $(83,5 \%)$ mahasiswa lebih cepat memahami materi geometri dengan menggunakan bantuan multimedia interaktif. Setelah melalui tahap evaluasi, tahap yang dilakukan selanjutnya adalah penyempurnaan media, dengan harapan media tersebut dapat dimanfaatkan secara optimal dalam proses pembelajaran untuk meningkatkan kemampuan geometris siswa dan kemampuan komunikasi matematis.

Pengembangan multimedia interaktif ini masih jauh dari sempurna. Beberapa kekurangan yang masih terdapat pada multimedia interaktif ini antara lain masih terbatasnya materi geometris yang dapat dipelajari oleh mahasiswa, karena multimedia interaktif ini hanya terbatas pada materi bangun datar. Selain itu permasalahan yang diselesaikan oleh mahasiswa juga masih terbatas.

\section{SIMPULAN}

Untuk mengembangkan multimedia interaktif terdapat beberapa langkah yang harus dilakukan yaitu concept, design, material, collecting, assembly, testing, dan distribution. Konsep dan desain multimedia interaktif ini dibuat semenarik mungkin dari segi warna dan animasi. Materi pada multimedia interaktif ini adalah bangun datar. Setelah dilakukan tahap uji coba di peroleh hasil bahwa sebagian besar mahasiswa senang belajar menggunakan multimedia interaktif ini. Pengembangan multimedia interaktif ini juga memiliki kekurangan yaitu terbatasnya materi ajar dan permasalahan yang diberikan kepada mahasiswa.

\section{DAFTAR PUSTAKA}

Clements D. H \& Battista M. T., (1992), Geometry and Spatial Reasoning, Handbook of Research on Mathematics Teaching and Learning, New York: MacMillan Publishing and Company

Crowley M. L., (1987), The Van Hiele Model of Development of Geometric Thought Learning and Teaching Geometri, National Council of Teachers Mathematics

Ditto. W., (2006), Multimedia, Encarta Ensyclopedia

Herman T., (2006), Pendidikan

Matematika I, Bandung: UPI Press 
Edutech, Tahun 13, Vol.1, No.2, Juni 2014

Mayer., (2001), Aplikasi Multimedia dalam Proses Belajar Mengajar, Mimbar Pendidikan

Rakim., (2009), Multimedia dalam Pembelajaran (OnLine), http://rakim_ypk.blokspot.com/2009 /4, [18 Januari 2011]
Sugiyono., (2011). Metode Penelitian Pendidikan. Bandung: Alfabeta. Sutopo, (2003), Multimedia Interaktif dengan Flash, Yogyakarta: Graha Ilmu 